\title{
GRK7 Gene
}

National Cancer Institute

\section{Source}

National Cancer Institute. GRK7 Gene. NCI Thesaurus. Code C24451.

This gene plays a role in signal transduction within the retina. 